\title{
Teatro narrativo, educação não formal e experiências de jovens ocupacionistas ${ }^{1}$
}

\author{
Denis Guilherme Ferreira Espanhol ${ }^{2}$ \\ Renata Sieiro Fernandes ${ }^{3}$
}

\begin{abstract}
Resumo
O objetivo é apresentar e analisar o teatro narrativo como prática de educação não formal a partir das experiências dos jovens alunos ocupacionistas. A linguagem do Teatro Narrativo é um caminho formativo inserido em um contexto de educação não formal. A pesquisa é qualitativa, descritiva e analítica e é do tipo participante contando com ações interventivas. A amostra de sujeitos conta com cinco jovens ocupacionistas na cidade de Santa Bárbara D'Oeste-SP e a técnica para a construção dos dados foi a entrevista com roteiro semiestruturado. Soma-se a amostragem cinco atores, que representaram cada um dos jovens na ação interventiva teatral. O material construído com os jovens e pelos atores foi utilizado para a criação da dramaturgia da peça intitulada "Educação Ocupada". Os dados foram analisados a partir dos conceitos de aprendizagem, narrativa, experiência e educação não formal. As categorias de análise que emergiram dos dados foram: a) poder de ação coletivo, b) lutar por direitos, c) insurgência, d) autonomia e maturidade, e) auto-organização e f) união. O referencial de ancoragem se baseia em Walter Benjamin, Luis Alberto de Abreu, Augusto Boal, Renata Sieiro Fernandes, Valéria A. Garcia entre outros. Conclui-se que a experiência narrativa dos jovens por meio do exercício de uma linguagem artística, no campo da educação não formal, torna-se ferramenta de formação, reflexão, questionamento e aprendizado para jovens, atores e público espectador.
\end{abstract}

Palavras-chave: Teatro Narrativo; Educação não formal; Ocupações juvenis; Arte; Ensino Médio.

\section{Narrative theater, non-formal education and experiences of young occupationalists}

\begin{abstract}
The objective is to present and analyze narrative theater as a practice of non - formal education based on the experiences of the young occupational students. The language of the Narrative Theater is a formative path inserted in a context of non-formal education. The research is qualitative, descriptive and analytical and is of the participant type counting on intervention actions. The sample of subjects is of five young occupationalists in the city of Santa Bárbara D'Oeste-SP and the technique for the construction of the data was the interview with semi-structured script. The sample consists of five more actors, who represented each of the young people in theatrical intervention. The material constructed with the young people and the actors was used for the creation of the dramaturgy of the piece titled "Occupied Education". The data were analyzed from the concepts of learning, narrative, experience and nonformal education. The categories of analysis that emerged from the data were: a) collective power of action, b) struggle for rights, c) insurgency, d) autonomy and maturity, e) self-organization and f) union. The anchorage reference is based on Walter Benjamin, Luis Alberto de Abreu, Augusto Boal, Renata Sieiro Fernandes, Valéria A. Garcia among others. The theoretical reference is Benjamin, Abreu, Boal, Fernandes, Garcia. It is concluded that the narrative experience of young people through the exercise of an artistic language, in the field of non-formal education, becomes a tool for training, reflection, questioning and learning for young people, actors and spectators. Keywords: Narrative Theater; Non-formal education; Youth occupations; Art; High school.
\end{abstract}

\footnotetext{
${ }^{1}$ A pesquisa contou com apoio do CNPq sob a forma de Bolsa PIBIC de iniciação científica.

2 UNISAL, Americana-SP, e-mail: renata.fernandes@unisal.br.

${ }^{3}$ UNISAL, Americana-SP, e-mail: denisgfespanhol@gmail.com.
}

$$
\text { Periódico Horizontes - USF - Itatiba, SP - Brasil - e019045 }
$$




\section{Introdução}

Segundo a Secretaria Estadual da Educação, duzentas escolas foram ocupadas em 2015, contra a reorganização escolar proposta pelo então governador do Estado, Geraldo Alckmin. Com essa medida, muitas escolas seriam fechadas e muitos alunos teriam de estudar em locais bem afastados de suas residências. É importante ressaltar que os estudantes de escolas públicas do Estado, em sua maioria, são os menos favorecidos da sociedade e que não possuem as mesmas condições que a classe média alta e rica ${ }^{4}$.

Em 2015, alguns colégios de Santa Bárbara D’Oeste-SP, lócus de investigação, também fizeram parte das duzentas escolas ocupadas, que tiveram como resultado a não conclusão da proposta do governador. Em 2016, as ocupações voltaram a acontecer contra a reforma do ensino médio que ficou conhecida como PEC (Proposta de Emenda à Constituição) 241. A falta de diálogo do governo para com os jovens alunos foi, nestes dois anos, os motivos para que eles precisassem exercer seu direito de luta social.

Se considera-se que os alunos do ensino básico obtiveram uma importante experiência por lutarem coletiva e socialmente por seus direitos, como o teatro poderia servir-se de suas memórias para criar um processo mútuo, formativo e educativo, compartilhado e pela via da vivência indireta (FERNANDES, 2007), que pudesse transpassar a barreira da experiência deles e atingir outras esferas, a dos sujeitos que não compreendem ou não conhecem suas lutas, e também por alunos ingressantes no ensino médio? Por que não oferecer como herança e lastro para os futuros alunos a experiência dos que vieram antes pela via da narrativa?

Muito do que se tem de informação sobre o movimento das ocupações das escolas por parte dos jovens alunos são conteúdos multiplicados pelas grandes e pequenas mídias, especialmente sob o ponto de vista dos que ficaram fora do movimento. Quantos de nós paramos para ouvir os jovens e refletir sobre sua luta social?

A experiência compartilhada pela via da narrativa colabora para que os jovens alunos desenvolvam a capacidade de se reconhecerem e de pertencerem a um coletivo. E como

\footnotetext{
${ }^{4}$ Uma parte dessa realidade é retratada em dois documentários: Lute como uma Menina (2016) e Ocupa Tudo: escolas ocupadas no Paraná (2016).
}

Periódico Horizontes - USF - Itatiba, SP - Brasil - e019045 
repercussão pode vir a atingir demais jovens alunos, especialmente do ensino público, que participam do mesmo sistema opressivo e excludente (sobre os gêneros, sobre as idades/gerações, sobre as classes sociais, sobre as origens étnico-raciais etc) e sofrem as mesmas consequências, uns mais que outros, de diferentes modos. Ter a conscientização disso é um estímulo para incentivar a ação participativa e/ou interventiva quando direitos são ameaçados ou violados.

A experiência dos jovens alunos pela via da narrativa pode contribuir para o imaginário coletivo da população oprimida e dos alunos herdeiros, que carecem ou que têm insuficientes exemplos atuais de mobilização e ação participativa e pode motivar novos exercícios de cidadania.

O Teatro é uma vertente de arte política. E, para os participantes, serve como prática educativa para fortalecer a capacidade de enfrentar os opressores pessoais, sociais, econômicos, culturais, étnicos etc. E como exercício da transmissão da experiência, passível de ser compartilhada e, por conseguinte, possibilidade de estimular a reflexão nos ouvintes e em seus públicos.

O teatro como expressão artística tem função política na sociedade se se considera que, enquanto cidadãos e participantes da sociedade, todos os atos são políticos. Inclusive o ato de ocupar, realizado pelos alunos de muitas escolas públicas do país que me motivaram a unir suas atitudes políticas ao fazer teatral e educacional.

Sendo assim, o objetivo deste artigo é apresentar e analisar o teatro narrativo como prática de educação não formal a partir das experiências dos jovens alunos ocupacionistas ${ }^{5}$.

Augusto Boal, teatrólogo e criador do Teatro do Oprimido, faz valer a ligação entre o teatro e a política,

[...] todo teatro é necessariamente político, porque políticas são todas as atividades do homem, e o teatro é uma delas. Os que pretendem separar o teatro da política pretendem conduzir-nos ao erro - e esta é uma atitude política (BOAL, 1991, p. 17).

\footnotetext{
${ }^{5}$ Ao fazer uma busca sobre as produções acadêmicas envolvendo os descritores ou palavras-chave, o Teatro Narrativo, jovens e Educação, no período dos anos 2000, nos sites SciELO (pela abrangência de artigos referentes a periódicos com as variações avaliativas da Capes) e IBICT-BDTD (pela abrangência de dissertações e teses oriundas de programas de Pós-Graduação), percebe-se que há poucas pesquisas realizadas sobre o Teatro Narrativo e a Educação, indicando uma lacuna investigativa.
}

Periódico Horizontes - USF - Itatiba, SP - Brasil - e019045 
Há mais dois elementos cruciais que justificam a atualidade da investigação: o primeiro é o aluno do ensino médio, que exerceu, coletivamente, sua cidadania ao agir ativamente na ocupação de suas escolas transformando a realidade a partir de uma luta social, e o segundo é a experiência pela qual passaram e que está registrada nas memórias de forma dispersa e fragmentada dos jovens ocupacionistas.

A narrativa é, na perspectiva de Benjamin, uma prática de "contar para refletir" e não "contar para informar". A diferença é que a narrativa, segundo Benjamin (1975), deve levar o seu ouvinte a reflexão:

A narrativa [...] é, por assim dizer, uma forma artesanal da comunicação. Sua intenção primeira não é transmitir a substância pura do conteúdo, como o faz uma informação ou uma notícia. Pelo contrário, imerge essa substância na vida do narrador para, em seguida, retirá-la dele próprio. Assim a narrativa revelará sempre a marca do narrador, assim como a mão do artista é percebida, por exemplo, na obra de cerâmica (BENJAMIN, 1975, p. 69).

É esta a concepção de narrativa que interessa ao teatro, aquela capaz de ajudar o público a conhecer e refletir. Uma história narrada atravessa de maneiras diferentes os ouvintes, ao contrário da informação, que só pode ser recebida como se mostra.

A capacidade de abrangência para interpretar e refletir sobre o que é narrado é o fundamento de uma narrativa. O narrador não interpreta, deixa essa tarefa para os ouvintes.

Abreu (2000), dramaturgo brasileiro autor de peças com a linguagem narrativa, esclarece sobre a importância do imaginário:

Um imaginário - repertório de imagens comuns a uma cultura e, em decorrência, de histórias, tipos, crenças, conceitos e comportamentos - é necessariamente uma criação coletiva. Mais, um imaginário é determinado por condições objetivas, sociais, históricas. Ou seja, não há a possibilidade de um indivíduo criar uma imagem fora do imaginário de seu meio. Por exemplo, na Idade Média seria possível haver um herege, mas nunca um ateu dentro daquele imaginário totalmente religioso. $O$ que não quer dizer que o imaginário não seja algo profundamente dinâmico. Cabe ao artista, ao homem criador, perceber, nas condições objetivas do processo histórico e social, as possibilidades de surgimento de novas imagens e dar luz a novas histórias, ideias, crenças, que vão integrar o imaginário de sua época (ABREU, 2000, p. 116-117). 
O autor também aponta a possibilidade (e fertilidade) do compartilhamento de algo que é pessoal, a partir do trabalho da memória e de sua comunicação pela via da narração.

Assim, por meio da força da experiência dos jovens ocupacionistas transmitida pelo teatro narrativo, é possível alcançar mais pessoas e galgar para reflexões mais profundas do que a mídia pode transmitir com suas informações diárias e excessivas e, muitas vezes, discriminatórias.

É possível perceber um entrelaçamento entre o campo da educação não formal e a arte teatral. A educação não formal é um campo crescente que abrange diversos tipos de pesquisas, experiências e transformações, inclusive sociais. O Teatro Narrativo é, portanto, um caminho prático e reflexivo que pode servir para a construção do campo da educação não formal, especialmente para o público jovem, abrindo novos caminhos e possibilidades de exercício de cidadania.

\section{Desenvolvimento}

Advinda do núcleo Narradores de Passagem, que visa a formação de narradores na atualidade, Saraiva (2009) apresenta e analisa a figura do narrador, embasando-se no papel tradicional deste apresentado por Benjamin, mas realizando as adaptações necessárias para os dias de hoje. O núcleo visita instituições para narrar histórias de passagem, buscando apoiar o ouvinte em sua luta social ou confortá-lo, afastando os aspectos excessivamente trágicos que a ideia dessas mudanças pode causar.

O primeiro elemento que Benjamin (1996) revela sobre o narrador é que ele está em extinção:

[...] a arte de narrar está em vias da extinção. São cada vez mais raras as pessoas que sabem narrar devidamente. Quando se pede num grupo que alguém narre alguma coisa, o embaraço se generaliza. É como se estivéssemos privados de uma faculdade que nos parecia segura e inalienável: a faculdade de intercambiar experiências. Uma das causas desse fenômeno é óbvia: as ações da experiência estão em baixa, e tudo indica que continuarão caindo até que seu valor desapareça de todo (BENJAMIN, 1996, p. 197-198).

Apesar de o narrador tradicional estar em vias da extinção, para esta pesquisa, é necessário levar em consideração que há uma "luta" para que haja uma restauração dos 
fragmentos que sobraram do narrador tradicional.

Benjamin (1996) considera como o sujeito do campo, do mar, da cidade, que aprendia com um saber passado por gerações, como um anel, como também afirma Abreu (2000).

Em um ensaio, Benjamin (1996) analisa que a perda do "poder" narrativo e da transmissão da experiência estariam também ligados ao trauma do mundo frente aos resultados da primeira guerra mundial:

No final da guerra, observou-se que os combatentes voltavam mudos do campo de batalha não mais ricos, e sim mais pobres em experiência comunicável. [...] não havia nada de anormal nisso. Porque nunca houve experiências mais radicalmente desmoralizadas que a experiência estratégica pela guerra de trincheiras, a experiência econômica pela inflação, a experiência do corpo pela guerra de material e a experiência ética pelos governantes. Uma geração que ainda fora à escola num bonde puxado por cavalos se encontrou ao ar livre numa paisagem em que nada permanecera inalterado, exceto as nuvens, e debaixo delas, num campo de forças de torrentes e explosões, o frágil e minúsculo corpo humano (BENJAMIN, 1996, p. 198).

Para Benjamin (1996), o narrador retira da experiência o que conta, seja a vivida pelo narrador, como é o caso dos jovens das ocupações ou a experiência indireta relatada por outros e captada enquanto o narrador estava na posição de ouvinte; isso também confere a passagem da experiência, que é o que acontece quando atores recebem a experiência relatada pelos jovens, seja por meio do texto escrito ou da fala e a retransmitem-na para o público. Então, o próprio público pode assumir, se quiser, o papel de narrador, tamanha é a força dessa experiência humana.

A grande inimiga da experiência narrada é a informação. Benjamin (1996) caracteriza o romance e a informação como opositores da narrativa e atribui, principalmente à informação, parte da responsabilidade pelo declínio da narrativa.

Para o autor,

Villemessant, o fundador do Fígaro, caracterizou a essência da informação com uma fórmula famosa. 'Para meus leitores', costuma dizer, 'o incêndio num sótão do QuartierLatin é mais importante que uma revolução em Madri'. [...] Cada manhã recebemos notícias de todo o mundo. $E$, no entanto, somos pobres em histórias surpreendentes. A razão é que os fatos já nos chegam acompanhados de

Periódico Horizontes - USF - Itatiba, SP - Brasil - e019045 
explicações. Em outras palavras: quase nada do que acontece está a serviço da narrativa, e quase tudo está a serviço da informação (BENJAMIN, 1996, p. 202-203). Ainda, em seu ensaio sobre a narrativa, Benjamin (1996) revela um exemplo valioso do que seria a narrativa, retirado de Heródoto, segundo ele, o primeiro narrador grego:

Quando o rei egípcio Psammenit foi derrotado e reduzido ao cativeiro pelo rei persa Cambises, este resolveu humilhar seu cativo. Deu ordens para que Psammenit fosse posto na rua em que passaria o cortejo triunfal dos persas. Organizou esse cortejo de modo que o prisioneiro pudesse ver sua filha degradada à condição de criada, indo ao poço com um jarro, para buscar água. Enquanto todos os egípcios se lamentavam com esse espetáculo, Psammenit ficou silencioso e imóvel, com os olhos no chão; e, quando logo em seguida viu seu filho, caminhando no cortejo para ser executado, continuou imóvel. Mas, quando viu um dos seus servidores, um velho miserável, na fila dos cativos, golpeou a cabeça com os punhos e mostrou os sinais do mais profundo desespero (BENJAMIN, 1996, p. 203-204).

A narrativa, na pele do narrador, não toma partido. Quem toma é o ouvinte, após vivenciar o conteúdo narrado. Isso não significa que o narrador não tenha um posicionamento sobre o que ele próprio narra, mas que o narrar não possui a necessidade de explicar. É uma linguagem que mostra, por meio das palavras, dos gestos e do corpo, o que foi vivenciado e isso atinge cada um de maneira particular.

Segundo Abreu (2000), as experiências são individuais e, no entanto, tomam forma de memória coletiva justamente quando são compartilhadas:

Não existe experiência coletiva. Existem acontecimentos, fatos coletivos, como a guerra, peste e morte que em determinado momento podem atingir indivíduo ou sociedade como um todo. No entanto, a experiência de cada um desses acontecimentos só pode ser absorvida individualmente. $O$ que não quer dizer que uma experiência não possa ser compartilhada, imaginada, comunicada e sensibilizada. Ao contrário, é de fundamental importância que toda experiência humana significativa possa ser comunicada tendo em vista a criação de um repertório comum de experiências, material básico para o desenvolvimento de uma consciência coletiva. E consciência coletiva é o que plasma o surgimento de um destino comum. E destino comum é o que orienta e dá forma ao que chamamos de comunidade, cidadania ou nação (ABREU, 2000, p. 3).

Ainda, sobre o exemplo de Heródoto, dado por Benjamin (1996), este explica a efemeridade da informação e como a narrativa perpetua a experiência: 
Essa história nos ensina o que é a verdadeira narrativa. A informação só tem valor no momento em que é nova. Ela só vive nesse momento, precisa entregarse inteiramente a ele e sem perda de tempo tem que se explicar nele. Muito diferente é a narrativa. Ela não se entrega. Ela conserva suas forças e depois de muito tempo ainda é capaz de se desenvolver. Assim, Montaigne alude à história do rei egípcio e pergunta: porque ele só se lamenta quando reconhece o seu servidor? Sua resposta é que ele 'já estava tão cheio de tristeza, que uma gota a mais bastaria para derrubar as comportas'. É a explicação de Montaigne. Mas poderíamos também dizer: ' $O$ destino da família real não afeta o rei, porque é o seu próprio destino'. Ou: 'muitas coisas que não nos afetam na vida nos afetam no palco, e para o rei o criado era apenas um ator'. Ou 'as grandes dores são contidas, e só irrompem quando ocorre uma distensão. $O$ espetáculo do servidor foi essa distensão'. Heródoto não explica nada. Seu relato é dos mais secos. Por isso, essa história do antigo Egito ainda é capaz, depois de milênios, de suscitar espanto e reflexão. Ela se assemelha a essas sementes de trigo que durante milhares de anos ficaram fechadas hermeticamente nas câmaras das pirâmides e que conservam até hoje suas forças germinativas (BENJAMIN, 1996, p. 204).

O que faz essa experiência narrada por Heródoto ainda estar viva é justamente ela não ser consumida. Quando se lê a história pela primeira vez, o que se encontra é o motivo frente à ação do rei egípcio. São várias as leituras, justamente, porque são várias as experiências individuais frente ao conteúdo narrado.

A reflexão causada pela narrativa dos jovens reverbera o efeito causado pelo exemplo de Benjamin (1996), como se observa no depoimento de uma jovem ocupacionista, constante do caderno “A Batalha do Vivo", do Grupo Contrafilé (2017), um coletivo de arte-política-educação:

O diretor da minha escola teve a proeza de, com uma semana de ocupação, levar a polícia para dentro da escola. Todo mundo apanhou, teve repressão, eu mesma levei um tapa na cara dele. Mas foi muito incrível porque nada disso adiantou. Eram 8 horas da manhã e estávamos apenas os que tinham dormido na escola, umas 12 pessoas. Eles eram uns 80 , o diretor, alguns pais, alguns professores, a polícia, todos contra a ocupação, dizendo que iam tirar a gente à força de lá porque precisavam fazer matrícula. Mesmo assim, a gente conseguiu recuperar a ocupação, que durou mais de um mês. E no dia em que fomos desocupar a escola, o diretor estava lá na porta, eu fui até ele e entreguei uma medalha de honra ao mérito (GRUPO CONTRAFILÉ, 2017, p. 47).

Por meio desta narrativa atual é possível refletir e explicar: "ela venceu ao resistir a um diretor que chegou a agredi-la?", ou "ela ironizou a garra do diretor em estar do lado opressor 
parabenizando-o pela competência frente ao estado?", ou ainda "ela reconheceu a derrota por meio da desocupação, entregou-se com uma medalha como forma de protesto?". As explicações variam conforme cada indivíduo avalia a experiência recebida da estudante, da mesma forma que cada um retira da história de Psammenit sua própria reflexão.

Abreu (2000) relaciona o declínio do imaginário coletivo com o declínio da narrativa reforçando o que Benjamin (1996) escreve:

No interior de uma noção forte de "corpo social" estabelece-se um imaginário comum de mitos, crenças, histórias, memória, etc. É do interior desse imaginário comum, público e permeável, que ao mesmo tempo em que invade a memória e os valores do indivíduo, abriga e agrega suas contribuições, que as pessoas extraíam o material para suas expressões simbólicas - ritos, mitos, arte. E foi de dentro de um imaginário e de experiências tornadas comuns que floresceu a narrativa como transmissora de conhecimento e, mais importante, de experiências individuais para o repertório coletivo. Qualquer alteração em quaisquer dos planos - o concreto e o simbólico - provoca alteração na forma de expressão humana. Esse é o raciocínio do filósofo Walter Benjamin, em seu ensaio primoroso 'O Narrador - Considerações sobre a obra de Nikolai Leskov' onde analisa a decadência da forma narrativa a partir das relações concretas do homem e o trabalho. A decadência da narrativa está intimamente ligada à decadência do imaginário comum (ABREU, 2000, p. 2-3).

O teatro entra como elemento artístico, transformador e educacional, mas antes da exibição a um público, é necessário o processo da criação e o da construção da dramaturgia textual a partir do material humano.

Sobre a dramaturgia, diz Abreu (2000):

Dramaturgia não é mais do que ler sinais por trás de uma ação ou de uma expressão humana. Em Medéia, Eurípedes nos revela um universo profundamente humano a partir de um crime bárbaro. O mesmo faz Ibsen que, a partir de uma pequena nota de página policial constrói Casa de Bonecas, um texto fundamental na moderna história da dramaturgia (ABREU, 2000, p. 1).

O teatro leva a narrativa dentro de sua forma dramática desde os gregos. O teatro como transmissor de experiências é muito importante para esta pesquisa, e quiçá, para a verdadeira essência desta arte. Não é incompreensível que se tem visto o abandono da forma dramática pura, para se adentrar cada vez mais na reconstrução da forma épica (narrada). 
Pavis (2008), em seu "Dicionário de Teatro", define a forma dramática como:

a. O dramático é um princípio de construção do texto dramático e da representação teatral que dá conta da tensão das cenas e dos episódios da fábula rumo a um desenlace (catástrofe ou solução cômica), e que sugere que o espectador é cativado pela ação. $O$ teatro dramático (que BRECHT oporá à forma épica) é o da dramaturgia clássica, do realismo e do naturalismo, da peça bemfeita: ele se tornou a forma canônica do teatro ocidental desde a célebre definição de tragédia pela Poética de Aristóteles: 'Imitação de uma ação de caráter elevado e completo, de uma certa extensão [...], imitação que é feita pelas personagens em ação e não por meio de um relato, e que, provocando piedade e terror, opera a purgação própria de tais emoções' (PAVIS, 2008, p. 110).

E a forma épica como:

b. O épico também tem seu lugar na prática e na teoria do teatro, já que não se limita a um gênero (romance, novela, poema épico), e desempenha um papel fundamental em algumas formas teatrais [...]. Mesmo no interior do teatro dramático, o épico pode desempenhar um papel, principalmente pela inserção de relatos, de descrição, de personagem-narrador (PAVIS, 2008, p. 110).

A forma dramática que Boal (1991) chama de "O sistema trágico coercivo de Aristóteles", desde a Grécia Antiga, tem sua força na catarse, ou seja, em fazer com que o público se emocione com a obra. Entretanto, apesar das lágrimas, não há a reflexão no seu sentido estrito. Não é negativo ter emoções sobre a obra, mas apenas ter emoções não é o bastante. Na necessidade de dar espaço à reflexão, a narrativa vem como um "balde de água fria" e permite ao público pensar sobre o que ele está vendo e ouvindo!

Boal (1991) define o poder do teatro como:

[...] pretendo igualmente oferecer algumas provas de que o teatro é uma arma. Uma arma muito eficiente. Por isso, é necessário lutar por ele. Por isso, as classes dominantes permanentemente tentam apropriar-se do projeto e utilizálo como instrumento de dominação. Ao fazê-lo, modificam o próprio conceito do que seja o 'teatro'. Mas o teatro pode igualmente ser uma arma de libertação. Para isso é necessário criar as formas teatrais correspondentes. É necessário transformar (BOAL, 1991, p. 13).

Outra explicação importante sobre o teatro é dada por Abreu (2000): 
Existem, a meu ver, dois elementos fundamentais que estruturam o que se convencionou chamar fenômeno teatral. E não é coincidência que esses mesmos elementos estejam também presentes tanto no mito quanto no rito religioso: o aqui e o agora. Teatro é uma arte efêmera e presente e isso quer dizer que sua existência se dá no momento em que o espetáculo acontece em sua relação com o público. Terminado o espetáculo, terminou a arte teatral. Teatro é uma arte que só tem existência em seu momento presente. Isso parece uma obviedade, mas é sua própria essência. Teatro é a ação presente, a emoção presente, $\mathrm{o}$ ator e o público presentes. [...] no teatro, e não falamos apenas do teatro grego, o êxtase necessita de um sentido, um logos, uma razão. [...] na arte, o êxtase é código de acesso ao logos, ao reconhecimento da trajetória humana. Teatro é também uma forma de saber (ABREU, 2000, p. 9-10).

É muito comum para uma parte da sociedade acreditar que o teatro se resume a sua forma dramática e é possível pensar que parte disso se deve a cultura da novela televisiva e a baixa procura da população pelo teatro. E as novelas fazem parte de um gênero que surgiu do dramático puro para receber o nome de melodramático.

O melodrama, o gênero preferido das novelas, preocupa-se em capturar o telespectador por meio da emoção com personagens exageradas e dicotômicas, como no caso do/a mocinho/a e do/a vilão/ã.

No dicionário de Pavis (2008), a definição deste gênero é:

O melodrama é a finalização, a forma paródica sem o saber, da tragédia clássica, cujo lado heroico, sentimental e trágico teria sido sublinhado ao máximo, [...]. Seu surgimento está ligado ao predomínio ideológico da burguesia que, nos primeiros anos do século XIX, afirma sua nova força oriunda da Revolução, substituindo as aspirações igualitárias de um povo apresentado como infantil, assexuado e excluído da história [...]. O melodrama sobrevive e prospera hoje no teatro de boulevard, nas telenovelas ou nos romances baratos e nas fotonovelas: livrou-se de seus instrumentos um tanto vistosos do romannoir ou do melodramático fácil, refugiando-se em mitos neoburgueses do casal ameaçado ou dos amores impossíveis (PAVIS, 2008, p. 238-239).

A narrativa, como técnica teatral, é escolhida para justamente fazer o público, este que está acostumado a apenas se emocionar na frente de uma televisão, pensar. Parece estranho afirmar que o teatro tem o intuito de fazer o público pensar, justamente, porque a visão geral revela o teatro como forma de lazer. Entretanto, o teatro não apenas faz pensar como transforma. E é essa transformação, de pensamento, que visa o teatro épico. Para isso é preciso 
abandonar o faz de conta e partir para a vivência e a reconstrução do que foi experienciado.

O melodrama surge quando a forma dramática abandona, totalmente, a forma épica. É como se a elite dominante utilizasse essa arma, que se chama teatro, como os imperadores romanos utilizavam o coliseu, e criasse uma espécie de "pão e circo" (forma adotada, na Roma Antiga, para ludibriar e manipular a sociedade) para a maioria da população.

Um dos responsáveis por reavivar o lado épico no teatro é Brecht, como nos diz Abreu (2000):

No século XIX o equilíbrio desses elementos [épico e dramático] foi fortemente alterado. Uma série bastante grande de fatores contribuiu para isso. E o teatro tornou-se um sistema fundamentalmente dramático. $\mathrm{O}$ exílio da narrativa no teatro provocou distorções. Uma delas pode ser verificada na artificialidade de alguns textos melodramáticos, no idealismo extremado, na bonomia inverossímil, no caráter maniqueísta de seus heróis e vilões. Os personagens, extraídos do contexto das relações humanas reais, tornam-se apenas emblemas de virtude ou vício. Afastados do fazer real, das relações humanas, a única realidade que resta é a subjetividade dos sentimentos. $O$ teatro torna-se mais e mais 'sentir', torna-se mais êxtase e emoção e menos saber. Nesses textos melodramáticos é até admirável a capacidade técnica dos seus autores em provocar emoção no público com personagens absolutamente desprovidos de humanidade. Personagens nessas peças são ferramentas hábeis para extrair emoção das plateias, mas muitas vezes não são, absolutamente, personagens pertencentes ao mundo real. A emoção paira exacerbada na atmosfera, mas carece de sentido. Talvez seja por isso que, hoje, nos causa riso o tom exageradamente emotivo desses velhos textos. Foi contra essa emoção fora de contexto que Brecht se insurgiu e com seu teatro épico propôs um novo reequilíbrio dos elementos épicos e dramáticos presentes no teatro (ABREU, 2000, p. 11).

Algo importante a se ressalvar é que, apesar do dramático existir sem o épico, este não se faz existir sem aquele. Tanto que a chamada "quebra da quarta parede", conhecida no teatro brechtiano, é justamente quando a personagem abandona o momento vivido (o dramático) por meio de um distanciamento, atravessa a "parede" que separa palco e plateia, conecta seu olhar no olhar do público e realiza a narrativa (o épico).

Abreu (2000) deixa clara a importância do olhar na narrativa:

No sistema narrativo, ao contrário, o público é o interlocutor privilegiado, a relação 'olho no olho' entre personagens no palco transfere-se para 'olho no

Periódico Horizontes - USF - Itatiba, SP - Brasil - e019045 
olho' entre ator/narrador/personagem e público. A ponte obstruída pela 'quarta parede' é novamente aberta. O sistema narrativo também lança mão da maior contribuição que público pode trazer ao espetáculo: uma imaginação ativa. Por meio da narrativa o público é também construtor das imagens do espetáculo e o espetáculo teatral, ao invés de ser um sistema predominantemente sensível, torna-se também um sistema fortemente imaginativo (ABREU, 2000, p. 12, grifos do autor).

É na conexão de olhares que a personagem-narrador ou o ator-narrador transfere sua experiência. É no olho no olho que a narrativa se estabelece. Quem narra não sofre, porque a matéria narrada pertence ao passado e já foi vivido, portanto, a matéria imaginativa surge do público, sendo este, inspirado pela narrativa. Imaginar e refletir sobre o que está ouvindo é o resultado, no público, do épico. Hoje, não faz sentido o teatro ser realista, justamente porque há novelas e filmes para esta finalidade. O teatro deve ser e mostrar o que ele é: palco ou rua, luz, ator/atriz e história, com material humano de base.

Em seu artigo, Abreu (2000) conclui que,

Bertolt Brecht com seu teatro épico apenas iniciou um caminho que pretendia um novo equilíbrio entre os elementos épicos e dramáticos existentes no teatro. Peter Weiss, Heiner Müller, Bernard-Marie Koltés e outros aprofundaram esse caminho, mas a pesquisa das possibilidades do sistema narrativo apenas se inicia. Creio firmemente que o sistema narrativo é um sistema de ganhos. É um sistema complementar ao sistema dramático/representativo e não exclui nenhuma conquista desse último. Ao contrário, provoca, lança desafios a todos os criadores e reintroduz o público como elemento construtor do espetáculo teatral. Sem a imaginação do público o teatro narrativo não existe (ABREU, 2000, p. 12-13).

Portanto, o teatro narrativo tem seu papel como ferramenta humanizadora de conhecimento. E não apenas para o público, mas para os participantes do processo. Afinal, antes de transmitir a experiência para quem assiste, o ator precisa tomá-la para si e, também, para os jovens que têm suas narrativas transformadas em dramaturgia, pois ter escrito sua própria experiência e torná-la fonte de saber é um processo inspirador e, potencialmente, transformador (ABREU, 2000).

O processo de ressignificação da experiência e da construção da dramaturgia tem caráter educacional e encontra-se nas possibilidades da educação não-formal. 
Segundo Fernandes e Park (2007), o termo sofreu diferentes interpretações ao longo do tempo:

\begin{abstract}
Um grupo de pesquisadores da Michigan State University, nos anos 70, inicialmente define o termo por antagonismo a educação formal-escolar, apontando o caminho inverso na construção de sua via, pontuando as diferenças em termos de flexibilidade maior em relação a: estrutura dos programas, formas dos conteúdos abordados, investimento temporal, fornecimento de uma certificação, locais de acontecimentos, métodos utilizados, participantes envolvidos e função. Posteriormente, nos anos 90, define o termo pensando em três funções: tendo papel complementar ao sistema formal-escolar, como uma alternativa e como papel suplementar. Nesse sentido, a oposição não é o foco, mas a perspectiva de ampliar as experiências escolares (FERNANDES; PARK, 2007, p. 131).
\end{abstract}

Segundo Garcia (2005), as diferenças entre os dois campos educacionais - o formal e o não formal - se resumem em um ser aberto a possibilidades e diálogos e o outro fechado em questões práticas e reprodutivas, não incluindo a diferença como modo relacional. Além disso, a educação formal é normativa e regulada por um órgão estatal, o MEC (Ministério da Educação e Cultura) enquanto que a não formal não segue uma legislação e regulamentação. É um campo aberto a experimentações e a resistências a argumentos homogêneos e hegemônicos.

A educação não-formal não deve ser significada como algo complementar, suplementar ou alternativo a formal-escolar e nem como campo opositivo. É importante dar autonomia para a educação não-formal não ser vista apenas como algo que sai, de alguma forma, da educação formal-escolar, ou que está contida nesta. E autonomia e independência fazem do campo teórico e prático da educação não-formal algo a ser levado em consideração e a ter importância própria. Sem operar na relação dual centro-periferia.

Fernandes e Park (2007, p. 132) explicam que Garcia (2005) “propõe que os conceitos [formal e não-formal] não apareçam em oposição, concorrência ou contraste, mas que sejam entendidos e pensados como conceitos autônomos, operando em campos conceituais independentes".

Segundo Garcia (2005):

A educação precisa permitir a irreverência para favorecer a criação. É importante que a educação crie espaços para essas outras relações de troca mais livres, sem pré-conceitos do que pode ser permitido no ambiente educacional e o que não foi previsto no planejamento possa se manifestar,

Periódico Horizontes - USF - Itatiba, SP - Brasil - e019045 
acontecer e que criações possam surgir desse imprevisto. Pois é perceptível que muitas vezes, o processo criativo acontece fora do âmbito escolar, sendo que até a criatividade tem limites nesse contexto. E para ser criação não pode ter limites, a não ser os impostos pelo seu próprio criador (GARCIA, 2005, p. 38).

Simson, Park e Fernandes (2001) atentam ao espaço que este funcione alimentador da prática de vivência social e que reforce o contato com o coletivo e estabeleça laços de afetividade com os sujeitos envolvidos.

A arte, por meio do teatro, é o espaço para a livre educação dos jovens, atores e público. Não que haja uma preocupação de que eles aprendam um conteúdo programado, mas sim que eles, lidando com seus papéis (ator e público), encontrem por si próprios o aprendizado que puderem. Não é o organizador da peça ou do texto que lhes levará o conhecimento ou a experiência artística. Ela estará na sala de criação e de apresentação para ser construída, experimentada e significada, pelos próprios participantes. Pela postura livre dessa educação pela arte é que o conceito de não-formal se faz necessário, pois segundo Garcia (2005):

O processo criativo não é tradicional e comportado. Deleuze e Guattari compreendem três instâncias de criação, que tem esses status, por saberem lidar com o caos. Os autores defendem que a arte, a ciência e a filosofia não se constroem sobre as bases da opinião e, portanto, não tentam escapar ao caos. Essas três áreas têm a pretensão de efetuar cortes no caos, possibilitando conviver com ele, sem pretender vencê-lo, mas aproveitando o potencial criativo do caos. A filosofia, a arte e a ciência mergulham no caos e criam a partir dele. Não significa que a filosofia, a arte e a ciência dominam o caos, mas colocam a possibilidade de viver no e com o caos, pois este é intransponível, invencível (GARCIA, 2005, p. 36-37).

A arte tem por si só a capacidade de conviver no caos, e o caos faz parte do processo criativo de qualquer artista. Portanto, os atores se abrem para o caos dentro da sala de criação, resgatam as experiências narradas pelos jovens ocupacionistas, transferem o que resgataram em forma dramatúrgica e constroem, no processo artístico de cada um deles, a narrativa teatral.

Garcia (2005) continua:

Não assumimos com isso que a educação não-formal tenha o papel de ensinar a criação, de ensinar a pensar, mas ela, se tem a intenção da transformação, tem o compromisso de favorecer diferentes possibilidades de exercício e vivência de diálogos nessa perspectiva de criação de pensamentos divergentes, opostos, contraditórios, diferentes, criativos, ousados etc. (GARCIA, 2005, p. 40).

Periódico Horizontes - USF - Itatiba, SP - Brasil - e019045 
Assim, se o teatro é por si só transformador e se a educação não-formal tem a intenção da transformação, pode-se concluir que o processo educacional não se finaliza apenas nos jovens ocupacionistas, nos atores ou no público, mas na rede de pessoas que a arte, a partir deles, alcança.

\section{Metodologia 6}

A pesquisa que dá origem a este artigo é de campo teórico e empírico, de abordagem qualitativa, de viés exploratório, descritivo e analítico quanto aos seus objetivos, e é do tipo participante contando com ações interventivas.

Sobre o desenvolvimento da pesquisa qualitativa em Educação

é preciso promover o confronto entre os dados, as evidências, as informações coletadas sobre determinado assunto e o conhecimento teórico acumulado a respeito dele. Em geral isso se faz a partir do estudo de um problema, que ao mesmo tempo desperta o interesse do pesquisador e limita sua atividade de pesquisa a uma determinada porção do saber, a qual ele se compromete a construir naquele momento (LÜDKE; ANDRÉ, 1986, p. 1-2).

E, ainda, "esse conhecimento vem sempre e necessariamente marcado pelos sinais de seu tempo, comprometido, portanto, com sua realidade histórica e não pairando acima dela como verdade absoluta. A construção da ciência é um fenômeno social por excelência" (LÜDKE; ANDRÉ, 1986, p. 2).

No desenvolvimento da investigação, a primeira ação tomada na pesquisa foi a busca de jovens ocupacionistas na cidade de Santa Bárbara D’Oeste, no ano de 2015 e a amostra de sujeitos contou com cinco estudantes, incluídos por adesão espontânea, que ocuparam a mesma escola.

Em virtude de incompatibilidade e indisponibilidade de horários dos cinco participantes,

\footnotetext{
${ }^{6}$ As abordagens e os instrumentos metodológicos utilizados obedeceram aos procedimentos éticos estabelecidos para a pesquisa científica em Ciências Humanas sendo a pesquisa aprovada pela Comitê de Ética a partir da Plataforma Brasil. CAE 80047617.7.0000.5379.
}

Periódico Horizontes - USF - Itatiba, SP - Brasil - e019045 
os encontros foram substituídos por entrevistas individuais online pelo programa de chamada virtual "Skype", e gravadas para estudo posterior pelo programa "MP3 Skype Recorder" entre maio e junho, com tempo aproximado de dez a vinte minutos.

As entrevistas se basearam em um roteiro semiestruturado organizado sobre a forma de perguntas temáticas em que se solicitou que criassem algo para representar toda a experiência vivida, podendo ser um desenho, uma poesia ou o que o jovem preferisse produzir. Também foi perguntado como eles se descreviam dentro da ocupação e que cenas extraíam da experiência.

Após as narrativas dos jovens, o segundo passo foi convidar cinco atores, que representaram cada um daqueles jovens no trabalho teatral. Os artistas convidados pertencem ao grupo Manada de Teatro da cidade de Americana/SP. O espaço utilizado foi um teatro alternativo na mesma cidade, o Fábrica das Artes. Cada ator e atriz recebeu um áudio gravado com as entrevistas. Eles ouviram as gravações, individualmente, e, por meio das informações obtidas, criaram, cada qual, o personagem que representaria cada um dos jovens. Neste ponto, os atores tentaram extrair a personalidade desses jovens por meio de suas falas, como por exemplo: se eram tímidos, indecisos, concisos, decididos, valentes, perceptivos, entre uma gama de possibilidades humanas.

O primeiro exercício com os atores foi a reprodução das entrevistas em audiovisual, gravado no palco do mesmo espaço. Refizeram a entrevista, interpretando os jovens e tentaram manter o fundamento, ou a personalidade de cada um ao passarem a experiência que receberam das narrativas originais. Assim, chegou-se à mesma narrativa sob duas vias: uma pelos áudios dos jovens e outra pelo audiovisual dos atores que interpretaram os jovens. O pesquisador assumiu, também, o papel de orientador/diretor artístico, sendo responsável por desenvolver as dinâmicas teatrais e trabalhar sobre o material retornado pelos atores a partir da experiência dos ocupacionistas.

O segundo momento com os artistas consistiu na reprodução das cenas contadas pelos ex-alunos do ensino médio. As cenas escolhidas foram: o fechamento do portão para dar início a ocupação; a distribuição de tarefas; a reunião com os moradores do bairro; o alarme que é confundido com a polícia; a visita da diretora escoltada por dois policiais; a escola rodeada por vinte e cinco viaturas; a vitória contra a péssima ideia do governo. 
Os artistas improvisaram os acontecimentos em grupo, criando no palco o que os jovens narraram nos áudios. O pesquisador, novamente, atuou como manejador do exercício, explicando no início da dinâmica o andamento das improvisações, como por exemplo, contando a história da cena em que o alarme da escola dispara e os jovens acordam assustados acreditando que a polícia havia invadido a ocupação; durante a improvisação, os atores foram deixados livres para viverem a narrativa ouvida. Todas essas experiências foram registradas em fotografias e gravadas em audiovisual, assistidas e selecionadas, posteriormente, com o fim de análises.

O material construído com os jovens e pelos atores foi utilizado para a criação da dramaturgia da peça intitulada "Educação Ocupada". Os personagens do texto teatral são cinco jovens ocupacionistas. Foram utilizados, na escrita, elementos do teatro épico/narrativo para que a peça fizesse o público pensar e refletir sobre as situações narradas. A dramaturgia indica os figurinos e o cenário construídos com aspecto escolar e ocupado com uniformes escolares (preferencialmente usados). Desta forma, as cenas, diálogos e conflitos foram todos criados com base no material coletado.

A pesquisa também contou com uma entrevista-piloto feita com Isabela Cristina Terra Saraiva, que participou do núcleo Narradores de Passagem e com Cláudio Mendel, diretor da Cia. Teatro da Cidade de São José dos Campos-SP, que possuem experiência e pesquisa acadêmica com a linguagem teatral narrativa. Ambos foram contatados via Skype e tiveram suas entrevistas gravadas pelo programa "MP3 Skype Recorder".

As entrevistas seguiram um roteiro semiestruturado e foram gravadas em áudio e transcritas. Após, foram organizadas sob a forma de temas e sistematizadas a fim de colaborarem para as análises dos dados.

O Diário de Campo foi usado como registro das observações, sensações, impressões e situações ocorridas ao longo de todo o processo de desenvolvimento da pesquisa.

\section{Análises dos dados}

Para iniciar, é necessário considerar o conteúdo das entrevistas realizadas com dois estudiosos da narrativa: Isabela Terra Saraiva e Cláudio Mendel e os diálogos estabelecidos com 
o referencial teórico de ancoragem.

As entrevistas contribuíram para a definição de narrador. Benjamin, em seu ensaio, já avisara sobre as mudanças ocorridas com a narrativa e até proclamara seu fim. Entretanto, ainda há luta para haver uma restauração dessa narrativa que se apresenta em vias da extinção, uma narrativa que provavelmente não será a mesma, mas que manterá a essência da transmissão da experiência. O narrador atual recebe formação para transmitir histórias e experiências.

No Núcleo de Narradores de Passagem, relatado por Saraiva, o primeiro passo era escrever as histórias narradas a partir de relatos pessoais do grupo, tendo assim material humano. Depois, havia um treinamento para a construção desse narrador. As perguntas que intermediavam esse treinamento era: "como eu forneço essa imagem sem me envolver com esse texto? Sem me emocionar com ele, mas fazendo que a pessoa que está ouvindo se emocione? Então como que eu gero essa sensação, que imagens que eu uso no meu discurso que vão tocar essa pessoa de alguma maneira?"

O núcleo realizava diversos exercícios corporais e vocais para chegar no formato de narrador. Eram, em média, quatro meses de trabalho para formar um narrador que estivesse pronto para acompanhar um narrador já formado até o hospital, para ver e participar como ouvinte, e então, apenas quando o narrador em formação se sente seguro, que ele pode começar a narrar as histórias, primeiro para o núcleo, e depois para os ouvintes do hospital ou asilo.

Segundo Isabela Saraiva: "A narrativa passava a fazer parte da gente, era como se a história fosse minha, então, você passava a ser o portador de uma história de uma outra pessoa. Era um narrador que acumulava experiências alheias. Acho que essa é a definição do narrador de passagem".

Segundo Mendel, tudo no cotidiano das pessoas passa pela narrativa, desde coisas simples, como relatar para o outro como foi o processo de acordar, de modo a fazer que o interlocutor consiga criar uma imagem de como foi acordar em tal dia. "É tão natural a narrativa que não precisamos pensar nela para utilizá-la", diz ele.

Quando a entrevista aborda a linguagem narrativa no teatro, os entrevistados retratam temas como o olhar, a transmissão das imagens narradas para o público e sobre a responsabilidade dos atores, que no caso são os detentores da narrativa. Quando perguntado se 
o teatro potencializa a narrativa, Saraiva diz:

O narrador quando olha no teu olho e tem essa experiência um para um, é diferente no teatro quando você está narrando para cento e cinquenta pessoas ao mesmo tempo e você não tem esse olhar direcionado para cada um. Ao mesmo tempo o texto é capaz de atingir várias pessoas no teatro enquanto que uma narrativa individual ela vai ser limitada naquele contato um para um. Então acho que o teatro potencializa no sentido de atingir um maior número de pessoas com aquele mesmo texto, então você consegue abranger um público gigante em menor tempo. E acho que ele não potencializa no sentido de contato humano, porque acho que você ter esse contato um para um, olho no olho, potencializa a experiência humana. Então acho que se tem o benefício de atingir mais pessoas em contrapartida a gente perde um pouco dessa relação olho no olho, um para um, contato próximo, que é uma relação humana. Mas se você está privilegiando a narrativa, o texto, eu acho que o teatro vai potencializar de forma mais eficaz o espalhar essa história pelo mundo, pelas pessoas. Eu acho que sempre partindo do, quando você tem experiência um para um, parte do narrador e da narrativa, e ali é criado uma relação humana, então é uma troca contínua e não tem de quem para quem, porque a partir do momento que você começa a contar e a olhar no olho de uma pessoa e essa pessoa se interessa pela sua história vocês se tornam um e os dois estão vivendo essa história juntos. No teatro eu acho que já é mais do ator para a plateia, então algumas pessoas vão estar vivendo essa história com você no momento, outras nem tanto, por conta da falta, de repente, de preparo do público ou falta de disponibilidade para vivenciar aquela história naquele momento, então acho que o contato é estabelecido com algumas pessoas, potencializado, mas não com todas no teatro, e acho que parte do ator sempre.

Mendel, respondendo a mesma pergunta, também ressalva o trabalho com o ator:

O ator ao buscar essa linguagem, obrigatoriamente ele vai precisar se aprofundar no conhecimento de si mesmo. Se eu ao invés de desenvolver um trabalho artístico como ator com base no que estou lendo do texto [teatral], se ao invés disso eu buscar em mim aquilo que corresponde ao que eu estou buscando no texto, isso será potencializado independentemente do texto. Não precisa usar o texto, não precisa falar o texto, precisa apenas vivenciar a situação. E ao vivenciar essa situação num palco ou numa sala ou em qualquer lugar, eu vou estar compartilhando com meu interlocutor, não o texto com aquela historinha, mas a minha história decupada em cena. Então, não é que eu vá me aprofundar e contar minha história de vida, mas eu vou de alguma maneira contar a minha história enquanto, por exemplo, Hamlet, porque eu tenho as mesmas informações enquanto pessoa que o Hamlet tem. Então, ao invés de procurar no texto uma maneira de criar essa personagem, eu buscar nas informações do texto o que me compete enquanto ser humano, a articulação do texto será uma mera consequência, porque a minha potência

Periódico Horizontes - USF - Itatiba, SP - Brasil - e019045 
existe independentemente desse texto, porque o texto me serve como pretexto para potencializar e verbalizar aquilo que é a minha sensação e o meu sentimento, e isso se dá no momento que eu me encontro com a plateia, este encontro é que faz essa coisa fantástica da comunicação humana [a narrativa] ser potencializada em segundos, que é o tempo necessário para o espectador criar as suas imagens e as suas histórias dentro daquela história que está sendo contada. É um absurdo lógico e meio complicado de teorizar, mas isso está presente na vida cotidiana, e aí é por essa cotidianidade a serviço da narrativa, no palco enquanto ator.

As entrevistas destes dois estudiosos da narrativa deixam claro que o principal desafio no processo ator e plateia, é o trabalho do ator de conseguir absorver a experiência que o objeto narrado propõe através de si mesmo.

As entrevistas com os jovens ocupacionistas buscaram extrair imagens das memórias dos jovens para servirem de material para a construção da dramaturgia, como foi a proposição da pergunta: Qual é a imagem mais preciosa para sua memória quando você se lembra da ocupação?

Ao que os jovens evocam: a) a lavagem e limpeza da escola, b) o recuo do governo, c) a reunião, d) o fechamento dos portões da escola no dia da ocupação.

(Aurélio ${ }^{7}$ ): Todos os alunos lavando a escola, limpando ela.

(Laura): O final. Quando o governo voltou atrás. Saber que tudo valeu a pena.

(Marcos): O dia de ocupar, da tomada de atitude.

(Márcia): No dia que teve uma reunião com a comunidade, e o pessoal pediu para eu fazer essa reunião. Todo o meu bairro onde eu nasci e cresci escutando o ponto da gente que até então era só molecada que brincava na rua.

(Júlio): Os portões da escola se fechando para dar início a ocupação.

Para a pergunta: O que você aprendeu com a ocupação? Os jovens respondem: a) poder de ação coletivo, b) lutar por direitos, c) insurgência, d) autonomia e maturidade, e) autoorganização e f) união.

(Aurélio): Eu aprendi que um número de pessoas juntos, com o mesmo ideal, tem poder de ação. Aprendi sobre solidariedade e sobre cuidados com a escola. Acho que foi para o lado da cidadania, de zelar pela escola. Eu nunca havia vivenciado uma situação em que, por exemplo, eu iria limpar a sala de aula.

\footnotetext{
${ }^{7}$ Os nomes são fictícios.
}

Periódico Horizontes - USF - Itatiba, SP - Brasil - e019045 
(Laura): Lutar pelo que é seu por direito.

(Marcos): Que a minoria acha que não tem tanto poder, mas se a minoria aprende a se juntar, ela descobre um poder para derrubar um governo ou uma ideia ruim, como foi o caso.

(Márcia): Um pouco mais de maturidade. Acho que minha vida adulta começou em 2015. A gente 'tava sozinho, era: 'vocês decidiram fazer isso agora aguenta'. Aprendi a tomar as rédeas da minha vida'.

(Júlio): Acho que o principal foi ensinar a gente a se auto organizar, trabalhar em grupo, porque se não tivéssemos nos unidos não teríamos conseguido nada.

Ao serem questionados sobre: Qual a pior memória da ocupação? Os jovens respondem:

a) pressão social, b) intervenção policial, c) o rótulo de vilania, d) agressões verbais, e) desconfiança dos professores.

(Aurélio): Acho que a pressão. De ser observado por todo mundo, estávamos cuidando da escola então todo mundo estava prestando atenção na gente. $\mathrm{E}$ a pior tensão era que a polícia ia chegar a qualquer momento, já corria boatos de outras escolas pertos que já haviam sido desocupadas pela polícia com ordem do juiz. Houve uma noite, depois de ouvir boatos de que a polícia estava vindo para nossa ocupação, que o sinal disparou e todos acordaram assustados achando que a polícia havia invadido, até que nos tocamos de que era apenas o sinal.

(Laura): Foi a intervenção da polícia, e não só isso. Quando a gente ocupou, foram pais na escola reclamar que estava uma bagunça. A pior parte foi a gente sair como errado na história tentando lutar por uma coisa que era nossa.

(Marcos): Teve um dia que a gente convidou a diretora para ela ir alguns dias da semana para ver como estava a escola, para ela ver que não 'tava bagunçada, mas era só ela. No primeiro dia que ela veio, ela estava com dois polícias, não aconteceu nada, mas só deles estarem ali, nós ficamos todos com medo, porque se entrou dois pode entrar mais.

(Márcia): O mais difícil foi quando houve uma reunião numa escola aqui perto e a nossa direção ia prestar esclarecimento sobre o que estava acontecendo e eu fui humilhada por uma família. Comecei a ser agredida verbalmente, e queriam até vir para cima de mim, fui chamada de tudo quanto é nome, que não prestávamos e éramos vagabundos. Fomos acusados de fazer coisas que não fizemos, como agredir um senhor que estava ali. Os professores que eram meus amigos começaram a me olhar torto e a falar sobre nós... foi difícil.

(Júlio): Acho que o momento mais tenso foi em outra ocupação, em 2016. No final do segundo dia, quando estávamos para fazer a janta, e umas oito da noite a polícia chegou e foi bem tenso, tinha um monte de viatura, cercaram a escola, eu lembro que estava eu e os meninos da segurança fazendo uma ronda, e quando estávamos no estacionamento começamos a ouvir um apito, a gente se olhou e caiu nossa ficha, era o sinal de quando a polícia chegasse. Havia 25 viaturas da PM contra um bando de estudante, queriam entrar de qualquer jeito e eles tinham mandato judicial, ficamos com muito medo, foi o momento mais

Periódico Horizontes - USF - Itatiba, SP - Brasil - e019045 
tenso.

Para a pergunta: Como você definiria seu papel dentro da ocupação? Como você se descreveria? As respostas foram:

(Aurélio): Insensato, indignado e revoltado.

(Laura): Sempre presente, fazendo tudo o que for preciso para ajudar. Desde limpar até coletar identidades.

(Marcos): Não é o mais ativo, mas ajuda na medida do possível.

(Márcia): Aquela que dá a cara a tapa, que bate no peito, veste a camisa e enfrenta.

(Júlio): Eu cumpria um papel organizado. Fazia as pontes entre outras ocupações e disseminava conhecimento.

Esse material mesclado de emoções, foi absorvido pelos atores, que apreenderam, por via da narrativa, a experiência destes jovens. Esse é o primeiro ponto em que há um processo de educação não-formal: política e história aprendidos por relatos de seus agentes. Portanto, os artistas envolvidos são os primeiros alvos desta transmissão de experiência que se intensifica quando passam a trabalha-la teatralmente.

Os exercícios realizados com os artistas funcionaram para aproximá-los da experiência que absorveram quando ouviram as entrevistas dos jovens. Assim, por meio dos dados, puderam criar, por improvisação, personagens que são capazes de transmitir a mesma experiência que receberam, agora, por via de uma dramaturgia também construída (pelo pesquisador) com o material narrado dos jovens, dramaturgia que tem o potencial de imortalizar essa experiência, através do teatro narrativo.

As cenas reconstruídas a partir das experiências dos jovens foram: a reunião com a comunidade do bairro; o fechamento dos portões; o susto do disparo do alarme da escola; a visita da diretora escoltada por policiais; as vinte e cinco viaturas cercando a escola e a comemoração dos jovens quando o governo voltou atrás. As cenas têm um grande valor por serem baseadas em experiências vividas. Assim, elas foram criadas com material humano, ou seja, seu teor é real e urgente.

O trecho abaixo, extraído da peça, apresenta a linguagem do teatro narrativo a partir do material fornecido pelos jovens ocupacionistas e retrabalhado pelos atores. Os personagens são 
os seguintes: Aurélio/Escola; Júlio/Escola; Laura/Escola; Márcia/Escola; Marcos/Escola.

(Ouve-se o barulho de giz escrevendo na lousa. O palco vazio mostra varais, cabides, manequins e o que mais houver, com uniformes escolares pendurados. Todo o cenário será construído a partir destas vestimentas. Cinco atores com roupas neutras podem ser vistos no meio dos uniformes, um deles toma a frente).

ESCOLA - Meu nome é Professora Mônica Margatto, mas todos me chamam de Margatto. Entretanto preciso avisá-los, não sou a Professora Mônica Margatto, eu sou o local batizado com o nome dela. Não fui feita de carne e osso, minha construção é concreto e tijolo. Não tenho sangue dentro de mim, o que tenho são adultos e jovens. Eu sou uma escola, e este (esta) ator (atriz) me empresta sua voz para que eu possa lhes contar a minha história, especificamente no ano de 2015, quando a ideia do governo foi reprogramar as escolas que os jovens poderiam estudar. Houve descontentamento por parte de muitos e o descontentamento se tornou ação. Preciso dizer: fui ocupada. Preciso dizer: fui resgatada.

(Os atores, com exceção daquele que empresta a voz para a Escola, escolhem um dos uniformes dos varais e vestem)

ESCOLA - Essa minha história cruza com outras cinco: estudantes que deixaram suas marcas nas minhas memórias. Registro que se tornou mais forte que os rabiscos que circundam minhas paredes. Maior que a idade dos meus telhados. Devo apresentar Márcia: (Uma atriz aparece acima dos uniformes) aquela que dá a cara a tapa, que bate no peito, veste a camisa e enfrenta!

(Os atores vão transformando o cenário de uniformes caóticos em um local de reunião. Alguns uniformes podem ser utilizados para representar mais pessoas) MÁRCIA Cantando - Não vão nos derrubar, minha escola não vão tomar! Podem me xingar! Podem se arriscar! A minha escola não vão tomar!

CORO DE ALUNOS Cantando - Não vão nos derrotar, nossa escola não vão roubar! Podem nos atacar! Podem nos criticar! Nossa escola não vão tomar!

MÁRCIA - Era um dia antes do fechamento dos portões, nós nos organizamos para explicar para o pessoal do nosso bairro que não íamos fazer baderna, colocar a escola a baixo. Mal sabíamos que a luta começaria muito antes dos portões se fecharem.

MARCOS - Aí pessoal! Veio muito mais gente do que o esperado, o bairro tá em peso aqui.

LAURA - Isso é bom ou é ruim?

MÁRCIA - Tem de ser bom, assim podemos ter o apoio da população!

(Dois atores se encontram afastados enquanto Marcos, Laura e Márcia se integram na reunião)

MÁRCIA - Boa tarde a todos os presentes. Eu primeiramente queria agradecer a presença de todos vocês. Como vocês sabem o governo tomou uma decisão ruim, que afeta a vida de todos os estudantes do bairro, se essa decisão vigorar, a gente vai ter que procurar escola em outros bairros, talvez até no centro, não vamos mais poder estudar na Margatto, e alguns de nós não tem condições de ficar arcando com circular todo dia, precisamos do apoio de vocês para que amanhã a gente consiga fazer uma ocupação organizada e pacífica! Vamos

Periódico Horizontes - USF - Itatiba, SP - Brasil - e019045 
ocupar a Margatto!

(Aplausos)

ATOR - Essa era a fala que Márcia havia ensaiado durante uma semana. Acontece que ela não chegou a ser concluída. Um pai cortou a fala da estudante depois do boa tarde e disse "vocês não tem vergonha de fazer tudo isso para ficar sem estudo?". Márcia e seus colegas tentaram argumentar. Sem sucesso. (O outro ator afastado começa a escrever em letras visíveis algumas palavras, como vagabunda, preguiçosa, bocuda e burra no uniforme de Márcia). Uma mãe ainda segurando uma criança no colo se descontrolou "tem que ser muito vagabunda mesmo! Isso é falta de surra, aí se uma filha minha ficasse metida no meio dos moleques pra dormir com eles dentro da escola! Você não tem vergonha na cara garota! Merece uns tapas no meio dessa fuça". Outros adultos tentaram acalmar os mais nervosos.

MÁRCIA - A reunião terminou sem muito consenso: poucos entendiam o que estava acontecendo no país. Os professores que foram na reunião, que eram meus amigos, começaram a me olhar torto e fazer comentários não muito melhores do que os da mãe descontrolada. Era o início. (A atriz tira o uniforme e o prende em um varal mais alto na frente do palco).

(Os atores preparam dois portões com uniformes presos em suas grades)

ESCOLA - Era o início e a luta deles não começou bem. Porém, eles não eram os professores que caminham pelos meus corredores cabisbaixos com o próprio serviço, eram os tantos jovens que formigavam dentro de mim, com fogo nos olhos e um temperamento imprevisível! Apresento-lhes agora, Aurélio: insensato, indignado e revoltado.

AURÉLIO Cantando - Fechai! Travai! O caminho deles bloqueai! Não sou filho de cordeiro. Sou bastardo sem dinheiro, não me envergonho na busca da vitória! Quem aqui vem comigo grita agora!

CORO DE ALUNOS Cantando - Aurélio!

AURÉLIO Cantando - Quem não tem medo dos capangas do governo agita sem demora!

CORO DE ALUNOS Cantando - Aurélio!

AURÉLIO Cantando - Quem vai ocupar a escola vibra toda hora!

CORO DE ALUNOS Cantando - Aurélio!

AURÉLIO - E é na contagem! Três, dois, um!

(Os portões são fechados no fundo do palco).

O teatro, ao utilizar-se da narrativa para atingir e afetar o público, proporciona reflexão e questionamentos e, assim, a peça "Educação Ocupada", resultado final deste processo, engloba o poder de criar um processo artístico e educativo para com o público. Portanto, maior que a transmissão e a provocação da experiência é o questionamento e a reflexão crítica, transformando posicionamentos.

\section{Considerações finais}

Periódico Horizontes - USF - Itatiba, SP - Brasil - e019045 
O objetivo principal, de desenvolver o teatro narrativo como prática de educação nãoformal a partir de uma dramaturgia escrita, foi realizado, porém, ainda é necessário que os artistas e/ou quem mais se interesse pelo tema não deixe essa experiência, transformada em arte, presa. É preciso manter a arte viva para que a experiência não fique banida. A promoção de uma prática educativa para os participantes também pode ser observada para os jovens e os atores. O mesmo se diz para o reforço da consciência político e social; dos jovens pela memória e transmissão, dos atores pelo ouvir, refletir, questionar, experienciar e representar e, provavelmente, do público pelo ouvir, refletir, questionar e experienciar. E, a transmissão da experiência com o objetivo da reflexão pode ser observada e identificada nos exercícios com os atores.

As entrevistas realizadas com os jovens foram essenciais para todas as etapas da pesquisa, porque são eles os detentores da experiência. As perguntas conseguiram recuperar na memória dos ocupacionistas o ardor das histórias vividas. Apesar da falta de tempo dos jovens, a internet serviu como facilitador para o acesso das memórias.

O processo de educação não-formal e artístico que se constituí em duas vias, jovens para atores e atores para público, é capaz de enfrentar a frieza da informação que acabou entregando os jovens ocupacionistas como desocupados e baderneiros. Mostra o potencial do campo da educação não formal em interface com a arte de manifestar a insurgência, de provocar práticas e exercícios de conscientização e deslocamentos, tirando os sujeitos de lugares de conforto, de aprisionamento, de colaborar para processos de transformação social que sejam mais inclusivos e mais humanos, não devastadores e não mantenedores do status quo.

O teatro narrativo pode realizar a transmissão da experiência de forma massiva, através do convite humano para o questionamento e para a reflexão, que são as "disciplinas" do povo que luta, bem como para o exercício da cidadania no cotidiano.

Conclui-se que a transmissão da experiência dos jovens é possível e pode ser mantida através da arte teatral como uma forma de vivência indireta e de memórias compartilhadas e reconstruídas a partir do tempo presente. 


\section{HSE}

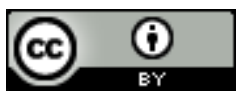

BY

DOI: https://doi.org/10.24933/horizontes.v37i0.739

\section{Referências}

ABREU, L. A. de. A restauração da narrativa. Inserir edição e editora. 2000. Disponível em: $<$ http://www.sesipr.org.br/nucleodedramaturgia/uploadAddress/A\%20Restauracao\%20da\%20 Narrativa[24539].pdf>. Acesso em: 27 set. 2018.

BENJAMIN, W. Experiência e Pobreza. In: BENJAMIN, W. Magia e técnica, arte e política. Obras Escolhidas, vol. 1. São Paulo: Brasiliense, 1996. p. 114-119.

BENJAMIN, W. O Narrador: considerações acerca da obra de Nikolai Leskov. In: BENJAMIN, W. Habermas. Adorno. Horkheimmer. Os Pensadores. São Paulo: Abril S.A. Cultural e Industrial, v. XLVIII, 1975, p. 63-82.

BOAL, A. Teatro do Oprimido e outras poéticas políticas. Inserir edição. Rio de Janeiro: Civilização Brasileira, 1991.

FERNANDES, R. S. Educação não formal: memórias de jovens e História Oral. Inserir edição. Campinas: UNICAMP/CMU/Arte Escrita, 2007.

FERNANDES, R. S.; PARK, M. B. Educação não formal. In: PARK, M. B.; FERNANDES, R. S.; CARNICEL, A. Palavras-chave em educação não formal. Holambra: Setembro, 2007, p. 131-133.

GARCIA, V. A. A educação não formal como acontecimento. Inserir edição. Holambra: Setembro, 2005.

GRUPO CONTRAFILÉ. A batalha do vivo. 2017. Disponível em: $<$ https://issuu.com/grupocontrafile>. Acesso em: 27 set. 2018.

LÜDKE, M.; ANDRÉ, M. Pesquisa em educação: Abordagens qualitativas. Inserir edição. São Paulo: EPU, 1986.

LUTE COMO UMA MENINA. Direção: Beatriz Alonso e Flávio Colombini, Documentário, Brasil, 2016, $76 \mathrm{~min}$.

OCUPA TUDO: Escolas Ocupadas no Paraná. Direção: Carlos Pronzato, Documentário, 2016, 58 $\min$.

PAVIS, P. Dicionário de Teatro. Inserir edição. São Paulo: Perspectiva, 2008.

SARAIVA, I. C. T. Um novo olhar à figura do narrador: Narradores de Passagem. 2009. 146p. Dissertação (Mestrado em Artes) - Instituto de Artes, Universidade de Campinas, São Paulo, 2009.

SIMSON, O. R. de M.; PARK, M. B.; FERNANDES, R. S. (orgs). Educação não formal: cenários da

$$
\text { Periódico Horizontes - USF - Itatiba, SP - Brasil - e019045 }
$$


criação. Inserir edição. Campinas, SP: UNICAMP/Centro de Memória, 2001.

Recebido em outubro de 2018.

Aprovado em junho de 2019. 